\title{
SCHILLER E OS GREGOS
}

\author{
Pedro Süssekind * \\ pedro.sussekind@terra.com.br
}

RESUMO Este artigo pretende mostrar como se articulam o helenismo classicista e a reflexão sobre a poesia moderna na teoria estética de Schiller, com base em uma breve análise de alguns ensaios do autor, levando em conta comentários de E. M. Butler (A tirania da Grécia sobre a Alemanha) e Peter Szondi.

Palavras-chave Estética, Poética, Antigo, Moderno

ABSTRACT This paper intends to show how Grecism and the consideration about modern poetry are articulated in Schiller's aesthetical theory, based on a brief analysis of some of his essays and on the commentaries of E. M. Butler (The tyranny of Greece over Germany) and Peter Szondi.

Keywords Aesthetics, Poetics, Ancient, Modern

Em A tirania da Grécia sobre a Alemanha, Butler considera Schiller como um "antagonista" de Goethe e, em certa medida, de todo o projeto classicista alemão baseado nas idéias de Winckelmann. ${ }^{1}$ Em certa medida, porque o autor

\footnotetext{
* Professor do curso de Pós-Graduação em Arte e Filosofia da Pontifícia Universidade Católica do Rio de Janeiro. Artigo recebido em 15/09/05 e aprovado em 15/11/05.

1 BUTLER. The tiranny of Greece over Germany, p. 164-200.
}

KRITERION, Belo Horizonte, $n^{0}$ 112, Dez/2005, p. 243-259 
foi um dos principais participantes desse projeto, incorporando à sua prática artística e à sua concepção teórica elementos característicos do Classicismo, como o estudo da arte antiga ou o esforço de distinção e definição dos gêneros artísticos. Para Butler, a posição de Schiller pode ser explicada por motivações pessoais e artísticas que se baseiam sobretudo na relação com Goethe. Os anos que antecederam a aproximação entre os dois escritores, quando ambos se afastavam do movimento pré-romântico, são decisivos para compreender essa explicação.

A Ifigênia em Táuris, publicada em 1787, quando o autor ainda se encontrava na Itália, foi um marco de consolidação da fase clássica na produção de Goethe, com a reelaboração de um tema grego (trabalhado também por Racine), em versos iâmbicos, respeitando as três unidades. No mesmo ano, após um longo período de preparação, publicava-se na Alemanha Dom Carlos, que marcava uma mudança decisiva na dramaturgia de Schiller, tanto na forma quanto no conteúdo. Em comparação com as peças anteriores, Os salteadores e Intriga e amor, identifica-se, por um lado, a transição dos dramas pessoais, em que o indivíduo aparece em conflito com as imposições da sociedade, para um drama político, sobre o rei da Espanha absolutista; por outro, trata-se da primeira peça do dramaturgo em versos iâmbicos, forma adotada também nas obras posteriores. Além da adoção de uma métrica que caracteriza, formalmente, o esforço dos dois autores de estabelecer o verso mais apropriado para a língua alemã, o projeto de Dom Carlos se identifica com o de Ifigênia por deixar de lado os personagens burgueses da fase anterior. Se as peças pré-românticas de Goethe e Schiller eram dramas burgueses, seguindo a ruptura de Lessing com a tradicional restrição à aristocracia, as duas peças que inauguram a fase clássica voltam a ter personagens nobres, como no teatro clássico francês.

Segundo Butler, Schiller considerou a Ifigênia de Goethe uma obra-prima justamente no estilo clássico que ele buscava com Dom Carlos, e um êxito muito maior do que o de sua própria peça. Essa comparação motivou não só o surgimento de uma certa rivalidade entre os dois escritores, consagrados no Sturm und Drang e em transição para uma fase nova de sua produção artística, mas também o grande interesse de Schiller pela Grécia antiga a partir de 1787. Pode ser considerado como uma primeira indicação desse interesse o poema Os deuses da Grécia, publicado em março de 1788, após a primeira visita do autor a Weimar. Nesse lamento pelos deuses que desapareceram, Butler vê a retomada de várias idéias do Classicismo alemão (de Wieland, por exemplo) e, principalmente, da imagem da Grécia evocada na Ifigênia de Goethe. Ele imagina Schiller maravilhado pela beleza da recriação goethiana da Antiguiidade, lamentando a sua impossibilidade de realizar algo semelhante. 
Em 1788, a partir da elaboração de Os deuses gregos, o poeta se dedicou intensivamente ao estudo da literatura antiga, decidido a não ler nenhum autor moderno por dois anos, como ele declara em carta de 28 de agosto a seu amigo Körner. O seu projeto consistia, a princípio, em estudar os gregos nas traduções alemães (como a de Homero por Voss), para depois ler os textos originais, apesar do pouco conhecimento do idioma grego. Em outra carta a Körner, o escritor resume seus objetivos:

Espero adquirir assim mais simplicidade no plano e no estilo. Depois, por meio de uma intimidade maior com as peças gregas, posso finalmente ser capaz de me apropriar dos elementos que são verdadeiros, belos e efetivos e, eliminando as imperfeições, devo formar um certo ideal a partir deles, segundo o qual o ideal que tenho agora será corrigido e aperfeiçoado. ${ }^{2}$

Esse projeto levou Schiller, mais tarde, a fazer uma tradução (incompleta) da Ifigênia em Áulis, de Eurípides, e de trechos da Ifigênia em Táuris, entre outros trabalhos. No entanto, se Schiller tinha decidido dedicar-se ao estudo dos gregos antigos e à busca de um ideal a partir desse estudo, sua postura em relação à Grécia, entretanto, não tem o caráter de veneração identificado em Winckelmann ou em Goethe. Aos poucos, os comentários a respeito das peças antigas em cartas ou ensaios deixam claro que, apesar do reconhecimento da sua importância, trata-se de uma postura muito mais crítica do que a de outros "helenistas". Na comparação da Ifigênia de Eurípides com a de Goethe, por exemplo, em um ensaio crítico que ficou incompleto, o escritor defende a superioridade da versão alemã, o que seria impensável para um classicista tradicional. Butler reconhece, nessa comparação, a intenção de defender a superioridade dos modernos sobre os gregos antigos, posição que caracterizará posteriormente o desenvolvimento da teoria da tragédia de Schiller. Assim, o projeto de estudo dos clássicos não o leva ao elogio da perfeição exemplar dos gregos, à defesa de um modelo a ser imitado, mas à tentativa de compreender o modo como os artistas modernos devem se aproximar do ideal expresso pela arte antiga.

Nos ensaios escritos entre 1791 e 1796, fica evidente o "antagonismo" do autor em relação às tendências nostálgicas do Classicismo. Depois dos anos dedicados aos estudos de Homero e dos tragediógrafos antigos, quando começa a desenvolver sua consideração de questões ligadas à tragédia, Schiller dá mais importância à dramaturgia moderna do que às peças gregas. Em "Acerca da razão por que nos entretêm assuntos trágicos" (1792), ele usa como exemplos

2 Ver BUTLER. The tiranny of Greece over Germany, p. 168-169. 
especialmente personagens de Shakespeare e nem sequer menciona Eurípides, cujas peças tinha começado a traduzir alguns anos antes. Já "Sobre a arte trágica" (1792) contém uma crítica da tragédia grega por sua "cega sujeição ao destino", considerada "humilhante e ofensiva" para a liberdade humana, e um elogio da arte moderna, esclarecida pela filosofia kantiana e destinada a alcançar por isso uma altura cristalina da emoção trágica. ${ }^{3}$ Schiller fala de uma "beleza excepcional na nossa Ifigênia alemã" e, de acordo com sua concepção da tragédia como expressão da liberdade, argumenta em favor da superioridade das peças modernas.

A defesa da superioridade da arte moderna poderia justificar o abandono do projeto de estudo dos antigos, iniciado em 1787 após a leitura da Ifigênia de Goethe, e o poema Os deuses gregos. No entanto, Schiller não só continuará a estudar os antigos e a buscar a definição de um ideal poético a partir desse estudo — como demonstra a correspondência com Goethe —, mas também participará ativamente do projeto classicista defendido, por exemplo, na revista Propileus. Assim, a relação do autor de Dom Carlos com a Grécia e com o Classicismo tem um caráter paradoxal, porque integra uma posição crítica, de defesa da arte moderna, a um reconhecimento da exemplaridade e da perfeição da arte antiga. Esse paradoxo só começa a ser esclarecido a partir da retomada da comparação entre antigos e modernos nas Cartas sobre a educação estética do homem (1795).

Na sexta carta do ensaio epistolar, o contraste entre a arte grega e a moderna não é apresentado em favor da humanidade mais recente, como no texto "Sobre a arte trágica". A "natureza grega", que "desposou toda a dignidade da arte e todos os encantos da sabedoria" aparece como ideal superior, nos moldes do Classicismo de Winckelmann, de quem o autor aproveita aliás a noção de "simplicidade". Schiller afirma:

Não é apenas por uma simplicidade, estranha a nosso tempo, que os gregos nos humilham; são também nossos rivais, e freqüentemente nossos modelos, naqueles mesmos privilégios com que habitualmente nos consolamos da inaturalidade de nossos costumes. ${ }^{4}$

Em outras palavras, os gregos são vistos como a realização máxima da cultura, oposta nas Cartas ao domínio da natureza segundo a reflexão sobre o homem como "cidadão de dois mundos". Identifica-se, então, uma decadência da modernidade no que diz respeito à relação entre natureza e cultura,

3 SCHILLER. Sobre a arte trágica. In: Teoria da tragédia, p. 94-95.

4 SCHILLER. Cartas sobre a educação estética do homem, p. 39. 
decadência exposta pela comparação com a civilização grega. Enquanto o indivíduo moderno se afasta da natureza e se torna fragmentário, governado pela arbitrariedade do Estado, exacerbadamente cultural, frio, mecânico, destituído de uma noção de totalidade, o grego aparece como estágio máximo da realização humana, no qual a natureza e a cultura se encontravam em harmonia. A crítica de Schiller não se baseia numa visão nostálgica da Antigüidade, mas visa justamente a uma reflexão sobre o ideal de harmonia entre o mundo da natureza e o da cultura, a ser buscado na modernidade. Nesse caso, a "educação estética" teria a possibilidade de orientar o homem moderno na direção desse ideal de algo que, na Grécia, existia como uma perfeição.

A décima quinta carta retoma a questão do modelo grego, no contexto de uma reflexão sobre o "impulso lúdico", que unifica o impulso sensível e o formal, o lado natural e o lado moral do ser humano. Schiller liga a noção de belo à noção de liberdade por meio dessa reflexão em que o impulso lúdico, ligado à criação artística, escapa tanto do constrangimento da natureza, quanto do constrangimento da razão. Com base na noção kantiana de "livre jogo" entre as faculdades do entendimento e da imaginação, o autor define a própria beleza como plenitude da humanidade, por envolver o "jogo" em que a matéria e o espírito aparecem unificados. Seu objeto é ao mesmo tempo forma (idéia) e vida (natureza), por isso o conceito de "forma viva" serve para designar a possibilidade de harmonia entre os dois "mundos", da natureza e da cultura, separados na modernidade. Assim como o homem não é exclusivamente matéria nem exclusivamente espírito, a consumação de sua humanidade não pode ser mera vida nem mera forma, ela deve ser "forma viva", criada pelo impulso lúdico.

Na concepção das Cartas, o homem deve "jogar" com a beleza, porque pelo impulso lúdico se alcança a plenitude de uma harmonia da "dupla seriedade" do dever (lei, moral) e do destino (natureza). Na décima quinta carta, os gregos são pensados como os mestres dessa concepção de plenitude humana como jogo, por terem feito "desaparecer da fronte dos deuses ditosos tanto a seriedade e o trabalho, que marcam o semblante dos mortais, quanto o prazer iníquo". ${ }^{5} \mathrm{O}$ ócio e a indiferença caracterizavam o divino como a existência mais sublime, verdadeiramente livre.

Toda a figura repousa e habita em si mesma, criação inteiramente fechada que não cede nem resiste, como se estivesse para além do espaço; ali não há força que lute contra forças, nem ponto fraco em que pudesse irromper a temporalidade. Irremediavelmente seduzidos por um, mantidos à distância por outro, encontramo-nos simultaneamente no 
estado de repouso e movimento máximos, surgindo aquela maravilhosa comoção para a qual o entendimento não tem conceito e a linguagem não tem nome.

Mas a constatação do belo ideal na escultura grega não leva Schiller à defesa incondicional do modelo grego. Mesmo nesse elogio dos "mestres" do impulso lúdico, há uma ressalva: eles transportaram para o Olimpo o que deveria ser realizado na Terra. Na conclusão de sua teoria sobre o belo e a arte, Schiller defenderá a noção de um "Estado estético", em que o impulso lúdico da criação artística educa o homem para a liberdade, harmonizando os reinos opostos das necessidades naturais ("reino terrível das forças") e da moralidade ("sagrado reino das leis"). Assim, o impulso estético ergue como ideal um terceiro reino, "de jogo e aparência", que "desprende o homem de todas as amarras das circunstâncias, libertando-o de toda a coerção moral ou física". ${ }^{6}$ Esse terceiro reino é, portanto, o reino da liberdade estética, que nos gregos aparecia como algo sobre-humano, divinizado, e que os modernos buscam como ideal.

A reflexão sobre os antigos e os modernos, presente na sexta e na décima quinta das Cartas sobre a educação estética do homem, foi retomada em Poesia ingênua e sentimental não para elaborar uma teoria do belo artístico, como no ensaio anterior, mas para definir dois modos de criação poética que caracterizam, por um lado, o antigo e o moderno, e, por outro, a poesia de Goethe e a de Schiller. Assim, a distinção entre ingênuo e sentimental tem tanto um aspecto histórico quanto um aspecto estilístico e pessoal. Como afirma Peter Szondi, em "O ingênuo é o sentimental", "o ensaio Poesia ingênua e sentimental tem assim uma tripla origem: os trabalhos poéticos de Schiller, sua tentativa de fundar, face a Goethe, seu próprio 'modo de criação poética', e a retomada dos princípios kantianos". ${ }^{7}$

Com essa indicação da origem, Szondi não pretende deixar de lado a questão dos antigos e dos modernos, uma das dimensões mais importantes do livro, mas apenas mostrar os pontos de partida que levam o autor a refletir sobre o problema histórico. Justamente a discussão desse problema constitui uma das questões que orientam a análise do ensaísta, como indica o título das conferências de 1970, que serviram de base para o seu ensaio "O ingênuo é o sentimental": "Antigos e modernos na estética da época de Goethe". Trata-se de saber se os conceitos de "ingênuo" e "sentimental" têm ou não um conteúdo histórico. Pela associação desses dois conceitos aos de "clássico"e "romântico", consagrados a partir da obra de Friedrich Schlegel como uma oposição

6 SCHILLER. Cartas sobre a educação estética do homem, p. 143.

7 SZONDI. Das Naive ist das Sentimentalische. In: Schriften II, p. 70. 
fundamental na história da arte, a resposta seria evidentemente afirmativa. É o próprio Goethe quem faz essa associação, ao declarar a Eckermann, em 21 de março de 1830, décadas após o falecimento de Schiller:

O conceito de poesia clássica e de poesia romântica, que hoje corre o mundo e tantas discussões provoca, veio originalmente de mim e de Schiller. Eu seguia na poesia a máxima objetividade e não queria aceitar nenhuma outra. Mas Schiller, que via tudo subjetivamente, considerava a sua atitude a única justa e, para se defender contra $\mathrm{mim}$, escreveu o ensaio acerca da poesia ingênua e da poesia sentimental. Demonstrava que eu, contra a minha própria vontade, continuava a ser romântico, e que a minha Ifigênia, por causa do predomínio que nela tem o sentimento, não era de modo algum clássica, ao gosto antigo, como se poderia supor. Os Schlegel se apoderaram da idéia e a lançaram, a ponto que hoje toda a gente fala de Classicismo e de Romantismo, quando há cinqüienta anos ninguém se lembrava de tal. ${ }^{8}$

Além de estabelecer a associação dos conceitos schillerianos com a oposição conceitual entre clássico e romântico, decisiva para todo o desdobramento do movimento romântico, nessa passagem Goethe dá a sua interpretação do propósito de seu antigo interlocutor. Segundo ele, Schiller escreveu o ensaio para se defender contra a exigência de objetividade, em nome de sua visão subjetiva das coisas, a fim de mostrar que mesmo no poeta "objetivo" moderno, ao abordar um tema antigo (a Ifigênia), predominava o "sentimento". Trata-se certamente de uma das dimensões mais importantes do ensaio, fundamental para a sua compreensão, mas é preciso levar em conta também outras dimensões.

Szondi questiona a identificação do par conceitual "clássico-romântico" como o par "ingênuo-sentimental", aceita por muitos intérpretes. René Wellek, por exemplo, autor da História da crítica literária 1750-1830 citada na conferência sobre o antigo e o moderno, considerava a segunda terminologia, de Schlegel, uma nova formulação, modificada, da teoria schilleriana. ${ }^{9}$ Essa associação direta é questionável exatamente porque os conceitos de Schlegel se referem a épocas históricas, enquanto os de Schiller, mesmo que façam referência aos antigos e aos modernos, caracterizam sobretudo modos de criação poética. O próprio autor considerou necessário chamar a atenção para esse fato em uma nota de Poesia ingênua e sentimental:

Talvez não seja supérfluo lembrar que, se aqui os poetas modernos são opostos aos antigos, a diferença não deve ser entendida como diferença de época, mas também como diferença de maneira. Também nos tempos modernos temos poesias ingênuas

8 ECKERMANN. Conversações com Goethe, p. 240-241.

9 SZONDI. Antike und moderne in der Ästhetik der Goethezeit. In: Poetik und Geschichtsphilosophie I, p. 150. 
em todas as classes, embora não mais da espécie inteiramente pura, e não faltam poetas sentimentais entre os antigos poetas latinos, e mesmo entre os poetas gregos. Não apenas no mesmo poeta, também na mesma obra amiúde se encontram ambos os gêneros unidos, como, por exemplo, nos Sofrimentos de Werther, e tais produtos sempre causarão o maior efeito. ${ }^{10}$

Não é à toa que a obra citada como exemplo seja de Goethe, já que o ingênuo diz respeito no ensaio tanto ao "antigo", para caracterizar o mundo grego, quanto a vários autores modernos, entre os quais o autor do Werther é o ponto de referência fundamental. Assim, a nota de Schiller pretende esclarecer uma imprecisão terminológica que se evidencia ao longo do livro, composto pela reunião de três artigos publicados na revista As Horas, em 1795 e 1796, "Do ingênuo", "Os poetas sentimentais" e "Conclusão do ensaio sobre os poetas ingênuos e sentimentais". Ao indicar essa imprecisão, Szondi chega a falar de um "labirinto terminológico", no qual o conceito de ingênuo designa ora os objetos e as ações que despertam o interesse do homem moderno que contempla a natureza, ora a poesia de Goethe, ora a Antigüidade; enquanto o sentimental define a cultura moderna, mas também está presente como modo poético entre romanos e gregos. Szondi procura a saída desse labirinto por meio de uma reflexão sobre a dialética conceitual do tratado schilleriano. Seu primeiro passo é desvincular os conceitos de ingênuo e sentimental da associação direta aos conceitos de clássico e romântico elaborados no Romantismo, embora reconheça a influência de uma distinção sobre a outra.

A importância de Poesia ingênua e sentimental sobre a estética posterior é apontada desde o início das conferências de Szondi como um fato amplamente conhecido. Wellek, por exemplo, afirmava que a teoria de Schiller se tornou a fonte de toda a crítica literária alemã posterior e que seu método foi seguido, em forma alterada, tanto pelos irmãos Schlegel quanto por Schelling e Solger. E dizia ainda: "Por intermédio de Coleridge, ele chegou à Inglaterra. Seu ponto mais alto foi alcançado na obra de Hegel, que, por sua vez, influenciou muitos críticos do final do século XIX (...)". ${ }^{11}$ Thomas Mann também considerava o livro de Schiller " $o$ ensaio alemão, no qual toda a ensaística alemã possível estava contida de uma vez", já que a estética alemã do século XIX girou em torno da oposição entre espírito e natureza e da tentativa de resolver essa oposição. ${ }^{12}$

10 SCHILLER. Poesia ingênua e sentimental, p. 61.

11 WELLEK. Geschichte der Literaturkritik 1750-1830, p. 236.

12 MANN. Ist Schiller noch lebendig?. In: Leiden und Grösse der Meister, p. 452. 
No início de Poesia ingênua e sentimental, o ingênuo é definido em três níveis: o do objeto, o da maneira de agir e o da poesia. Assim, em primeiro lugar, trata-se do objeto ingênuo e do interesse que ele desperta "em nós", sendo a primeira pessoa do plural usada para caracterizar a perspectiva moderna chamada depois de sentimental. O autor constata "uma espécie de amor e comovente respeito à natureza", tanto no âmbito das coisas naturais, como plantas, animais, minerais e paisagens, quanto no da natureza humana, nas crianças, nos "costumes da gente do campo", no "mundo primitivo". Com esse último exemplo, começa a se delinear a questão histórica que será abordada mais adiante, já que Schiller parece igualar, no conceito de ingênuo, as paisagens naturais e os "monumentos de tempos antigos", ou os "produtos da Antigüidade remota". A definição do conceito de ingênuo tem como ponto de partida a constatação desse sentimento de amor e respeito que é despertado, no homem moderno refinado e sensível, quando ele é surpreendido pela visão da natureza simples em meio a relações e situações artificiais. Tal interesse ocorre apenas sob duas condições: a de que o objeto seja natureza e a de que ele seja ingênuo, isto é, a de que "a natureza esteja em contraste com a arte e a envergonhe". ${ }^{13}$

A elaboração do conceito de ingênuo nesse primeiro momento retoma os princípios kantianos da teoria estética anterior de Schiller. Identifica-se no homem moderno uma cisão entre o mundo natural e o cultural ou racional, e o que se busca é a possibilidade de restabelecer a ligação entre os dois mundos separados. É nesse sentido que se pode entender a afirmação segundo a qual amamos na natureza ingênua não os objetos, mas a idéia exposta por eles. Trata-se da idéia de uma autonomia, do tranqüilo atuar por si mesmos, da unidade e da necessidade; portanto, daquilo que o homem moderno perdeu. Sendo determinado por todas as convenções do mundo cultural e incapaz de um gesto espontâneo, seguindo leis morais, o homem moderno comove-se com os objetos em que vê representadas a força pura e livre da natureza, a integridade e a infinitude. Assim, o que define o ingênuo é uma vitória da natureza sobre a arte, entendendo-se arte no sentido de um caráter artificial que predomina na modernidade.

Os objetos ingênuos são natureza: "são o que nós fomos; são o que devemos vir a ser de novo." A natureza é definida aqui como a subsistência das coisas por si mesmas, a existência segundo leis próprias e imutáveis. Assim, o que se defende não é a imitação artificial das formas naturais, porque o interesse em tais objetos diz respeito ao fato de serem espontâneos, expondo uma idéia contrária às limitações impostas pela artificialidade do mundo moral. O que 
esses objetos são é o que deve ser buscado como ideal. "Fomos natureza como eles, e nossa cultura deve nos reconduzir à natureza pelo caminho da razão e da liberdade." Para usar uma metáfora recorrente no ensaio, eles são "expressões de nossa infância perdida, que para sempre permanece aquilo que nos é mais precioso; por isso, enchem-nos de uma certa melancolia". ${ }^{14}$

Para reforçar a metáfora da "infância perdida", Schiller dá como exemplo de objeto ingênuo a criança, na qual se expõe para nós a espontaneidade e a "determinabilidade ilimitada", diante da qual a determinação do homem adulto aparece como uma limitação. É com esse exemplo que o autor procura esclarecer o segundo nível do conceito de ingênuo, quando ele não diz respeito aos objetos, mas ao modo de agir e de pensar. Neste segundo momento, o autor define como ingênua a ação de uma criança que, ao ouvir a explicação de que a pobreza é a causa do estado precário de um homem, pega a bolsa do pai e a entrega ao pobre. Essa ação estaria perfeitamente certa caso a natureza saudável predominasse no mundo social, caso a questão da pobreza pudesse ser remediada de maneira imediata, mas a desigualdade social não deriva de condições naturais. No mundo social, a ação é "vergonhosa", porque demonstra uma falta de conhecimento das regras estabelecidas, no entanto, seu caráter espontâneo, ou seja, sua ingenuidade pode despertar no pai uma satisfação respeitosa em que se expõe a idéia de um mundo natural harmonioso. Schiller dá ainda outros exemplos a esse respeito, a fim de analisar ações e atitudes ingênuas, mas o exemplo e a metáfora da criança são os mais usados no início do ensaio, porque "nossa infância é a única natureza intacta que ainda encontramos na humanidade cultivada". ${ }^{15}$

Em um terceiro momento, o ensaio sobre o ingênuo volta-se para a questão da poesia, retomando à noção kantiana de gênio como alguém que não segue as regras da arte e, orientado pela natureza ou pelo instinto, seguindo inspirações e sentimentos, cria novas regras. E é na reflexão sobre o ingênuo na poesia que se evidencia, nessa primeira parte do livro, a questão dos antigos e dos modernos. Por trás dela se pode identificar uma retomada, em novo contexto, da defesa da arte moderna e da discussão sobre o modelo clássico, temas que definem a relação do autor com o Classicismo.

Também é na discussão sobre os gregos e os modernos que começa a ser definido, de maneira mais direta, o conceito de sentimental. Os poetas são pensados por Schiller como guardiões da natureza, de modo que, quando a sua relação imediata com a natureza é abalada, quando experimentam a influência 
de uma cultura artificial, precisam recuperar essa relação. Em outras palavras, ou os poetas são natureza (caso do gênio ingênuo, que cria movido por um dom natural, sem refletir), ou buscam a natureza perdida. "Daí nascem duas maneiras de criar completamente distintas, mediante as quais se esgota e mede todo o domínio da poesia”. Assim, o sentimental define-se em oposição ao ingênuo, sem remeter apenas à distinção de épocas, mas também à distinção de modos que podem coexistir na mesma época e que terão seu sentido analisado especialmente na situação histórica do próprio Schiller. Em suas palavras: "Todos os que realmente são poetas pertencerão ou aos ingênuos ou aos sentimentais, conforme seja constituída a época em que florescem ou conforme condições acidentais exerçam influência sobre a formação geral ou sobre a disposição momentânea de suas mentes".

Para Schiller, os poetas ingênuos já não estão em seu lugar numa época artificial do mundo, como a moderna, por isso é a poesia sentimental que se impõe na modernidade a quem pretende realizar a tarefa de "guardião da natureza". Em outras palavras, mesmo na época do homem artificial, inserido na cultura que não tem mais naturalidade, é a natureza que alimenta o espírito poético, exigindo uma busca da harmonia perdida. Por isso, para que haja poesia, é preciso que a unidade e a relação de harmonia com a natureza identificada no modelo do passado humano apareçam como um ideal. Essa constatação de que o momento histórico se caracteriza pela artificialidade está na base tanto da comparação entre antigos e modernos, quanto da reflexão de Schiller sobre os modos poéticos existentes em sua época.

Os dois conceitos são definidos na primeira parte do ensaio um em função do outro, o que deixa clara a sua interdependência. $O$ ingênuo só se revela como ingênuo aos olhos do homem moderno, isto é, sob a ótica do sentimental, que, justamente por sua condição artificial, se interessa pela natureza e ama a idéia exposta por objetos e ações naturais. Assim, o sentimental busca, por sua vez, exatamente o que o ingênuo é (natureza), assumindo como ideal aquilo que constitui no outro uma situação de fato. No resumo de sua argumentação, feita no que era originalmente o início do segundo artigo publicado em As Horas, Schiller afirma: "A natureza também agora é a única chama de que se alimenta o espírito poético; somente dela extrai todo o seu poder e somente para ela fala, mesmo no homem artificial inserido na cultura". ${ }^{16}$ Assim, se ingênuo e sentimental definem as épocas antiga e moderna, o fazem como modos característicos de se relacionar com a natureza.

16 SCHILLER. Poesia ingênua e sentimental, p. 60. 
Identifica-se um modo natural, ou seja, espontâneo, harmonioso, no qual o indivíduo age moralmente de acordo com suas inclinações, e um modo artificial, fragmentado, no qual as inclinações se encontram em conflito com as leis morais. O primeiro modo caracteriza a "bela natureza" dos gregos, esse povo que "podia viver com a natureza livre sob seu céu feliz". Schiller observa como estavam próximos "da natureza simples seu modo de representar, sua maneira de sentir, seus costumes, e que reprodução fiel dela são suas obras poéticas". ${ }^{17}$ Já a relação artificial com a natureza diz respeito aos modernos, mencionados em primeira pessoa do plural: “(...) cindidos de nós mesmos e infelizes em nossa experiência de humanidade". Por isso, aos olhos do homem moderno, o modo de ser natural dos gregos é ingênuo, ou seja, ele representa uma vitória da natureza sobre a cultura, despertando, assim, um amor carregado de nostalgia. Trata-se do mesmo processo exemplificado pela infância em relação ao homem adulto.

Schiller não pretende defender a superioridade dos antigos, mas procura entender a questão da sua exemplaridade no contexto de uma justificativa da poesia moderna. Para ele, o interesse pela perfeição da Antigüidade pode muito bem levar a um elogio de sua arte em detrimento da arte moderna. "Por isso, ou não se deveria de modo algum comparar poetas antigos e modernos ingênuos e sentimentais -, ou só se deveria compará-los sob um conceito mais alto comum a ambos", o conceito de poesia. ${ }^{18}$ Nesse caso, o resultado da reflexão sobre antigos e modernos segundo os termos ingênuo e sentimental possibilita um questionamento do modelo antigo, sem levar a seu abandono. A cultura moderna não deve ser vista como inferior à antiga, mesmo que a tenha como modelo de perfeição e de harmonia, justamente porque restabelecer o padrão antigo, a forma antiga, não é o que ela busca.

Essa reflexão sobre o modelo grego remete, segundo a indicação de Szondi, à relação com a natureza e, com isso, à questão da imitação. Neste sentido, o ensaio Poesia ingênua e sentimental pode ser entendido como a justificativa teórica da posição de Schiller a respeito do Classicismo. Basicamente, essa posição se fundamenta em uma crítica da noção de uma volta ao passado, tanto no caso de um retorno à natureza nos moldes de Rousseau, quanto no de um retorno ao modelo grego nos moldes do Neoclassicismo, baseado em Winckelmann. O estado natural, com o qual se identifica a harmonia dos gregos com a natureza, ficou para trás e não pode ser restabelecido. Querer voltar a ele seria um desejo semelhante ao do adulto querendo voltar a ser criança. $\mathrm{Na}$ 
descrição do "amigo sentimental" que contempla a "tranqüila felicidade da natureza", Schiller chama a atenção para o fato de que as queixas contra a cultura se dirigem às suas falhas, mas devem levar em conta as conquistas culturais para a liberdade humana. Na natureza, o homem não é livre, ele está submetido às necessidades naturais, limitado por suas imposições. Por isso, $\mathrm{o}$ autor afirma: "Aquela natureza que invejas no irracional não é digna de nenhum respeito nem de nenhuma nostalgia. Ela permanece atrás de ti, tem de permanecer sempre atrás de ti”. A perda da felicidade na natureza é uma condição para a liberdade na cultura.

Para Szondi, é como se Schiller quisesse "dar um fim às queixas e devaneios do promeneur solitaire [de Rousseau] e lhe pusesse nas mãos, em lugar do lenço molhado de lágrimas, um exemplar da Crítica da Razão prática" ${ }^{19}$ É com base na filosofia de Kant que Schiller defende a cultura moderna, apesar de todas as suas falhas, em nome da razão e da liberdade. Mas tanto a infância quanto a Antigüidade despertam um interesse, um sentimento de respeito mesclado com nostalgia, porque têm aos olhos do adulto ou do homem moderno um caráter ingênuo, no qual se encontra representado o que a humanidade perdeu ao se afastar da natureza. Por isso, o autor recomenda ainda: "Mas se estás consolado da perda da felicidade da natureza, deixa que a perfeição desta sirva de modelo para o seu coração" ${ }^{20}$ É assim que ele introduz a sua consideração sobre os gregos, pensados como modelos de perfeição (ingênua) que devem acender "a chama do ideal".

A poesia ingênua e antiga é designada como um favor da natureza, para ressaltar tanto a ausência da reflexão, quanto o seu caráter fortuito, encerrado nos limites da sensibilidade. É por sua própria natureza que o gênio ingênuo dá plena expressão à humanidade, de modo que ele está sujeito à necessidade natural e depende inteiramente da experiência. Sem um mundo rico em formas, sem um mundo poético de harmonia com a natureza, a tarefa do poeta ingênuo torna-se impossível. Já a poesia sentimental tem, como seu auxílio, "a liberdade incondicionada da razão", de modo que não depende da experiência para criar, mas da reflexão contemplativa que se volta para fora e, assim, busca a natureza. Irremediavelmente separado da natureza, o poeta sentimental tem de completar o seu objeto, dar a ele a plenitude que lhe falta, por isso, transporta-se "de um estado limitado a um estado de liberdade". Sua tarefa, assim como a do poeta

19 SZONDI. Antike und moderne in der Ästhetik der Goethezeit. In: Poetik und Geschichtsphilosophie I, p. 157. A mesma frase é usada no ensaio "Das Naive ist das Sentimentalische" ["O ingênuo é o sentimental"], em Schriften II, p. 75-76.

20 SCHILLER. Poesia ingênua e sentimental, p. 54. 
ingênuo, é expressar a plenitude da natureza humana. Mas, no mundo moderno cultural e artificial, não faz sentido a noção de retorno à natureza, já que a própria intenção tem uma base artificial. Em vez de buscar o restabelecimento do ingênuo, o que o homem moderno deve buscar é o ideal de uma harmonia que o ingênuo representa. Assim, em Poesia ingênua e sentimental, não é o passado que constitui o ideal, mas o futuro.

No entanto, Schiller também não critica o ingênuo em favor do sentimental, ou o antigo em favor do moderno. Os poetas antigos e modernos só podem ser comparados segundo um conceito mais alto, comum a ambos: o próprio conceito de poesia, como gênero a que tanto o ingênuo quanto o sentimental pertencem. $\mathrm{O}$ que o ensaio defende é a existência de uma vantagem em cada modalidade, como argumenta o resumo que originalmente introduzia o terceiro artigo publicado em As Horas, no qual se conclui a reflexão elaborada nos dois primeiros. "Ao poeta ingênuo, a natureza concedeu o favor de sempre atuar como uma unidade indivisa, de ser a cada momento um todo autônomo e acabado, e de expor a humanidade na realidade segundo seu conceito inteiro". Assim, o primeiro modo de criação poética define-se por um favor da natureza, um dom natural de harmonia entre o lado sensível e o racional. Comparativamente, o poeta sentimental é dotado de um "vivo impulso para restabelecer por si mesmo aquela unidade nele suprimida por abstração, a fim de tornar a humanidade completa em si mesmo, passando de um estado limitado a um infinito". ${ }^{21}$

Segundo Schiller, a tarefa da poesia, comum ao poeta ingênuo e ao sentimental, é a de dar expressão plena à natureza humana. Nesse caso, há uma vantagem do poeta ingênuo por apresentar como real, com perfeição, essa natureza que o poeta sentimental apenas se empenha em alcançar como ideal. Entretanto, "toda realidade permanece aquém do ideal", porque tudo o que existe tem seus limites, mas o pensamento é ilimitado, de modo que o poeta sentimental tem a grande vantagem de ter uma "tarefa infinita". Assim, a caracterização das duas espécies poéticas é pensada com base na noção de "limitação" e "infinito", ligada à identificação de duas vias para realizar a tarefa de "dar à humanidade a sua expressão mais completa possível". Pela via da unidade e da harmonia com a natureza, "o que tem de construir o poeta é a imitação mais completa possível do real"; pela via de uma busca da idéia de harmonia, "o que tem de construir o poeta é a elevação da realidade ao ideal". ${ }^{22}$ Em termos comparativos, a primeira via caracteriza os antigos, e a segunda, os

21 SCHILLER. Poesia ingênua e sentimental, p. 88.

22 Ibidem, p. 61. 
modernos. Quanto à realização da tarefa, a vantagem é da poesia antiga, ingênua, que chega ao ponto de perfeição na imitação do real. Quanto à meta a ser atingida, a vantagem é da poesia moderna, sentimental, que busca o ideal infinito de uma harmonia com a natureza a partir da cultura, a partir da liberdade.

Do mesmo modo que o poeta sentimental busca o ideal de harmonia com a natureza identificado no ingênuo, porque a sua tarefa é a de ser um "guardião da natureza", o poeta ingênuo se torna sentimental para continuar a ser poeta, alcançando pela reflexão aquilo de que a época o privou. Nesse caso, o ensaio indica uma meta em comum, a partir de caminhos opostos, ligada ao conceito do gênero (poesia) no qual os dois conceitos discutidos se incluem.

Segundo Goethe, o ensaio de Schiller foi escrito para se defender, para justificar sua posição especulativa e subjetiva diante da exigência de objetividade, do caráter intuitivo genial de seu interlocutor. A possibilidade da poesia ingênua em uma época sentimental pode ser considerada como uma justificativa do Classicismo, no contexto de um questionamento de seu modelo. Ao mesmo tempo, Schiller condena a noção de volta ao passado e pensa os antigos como modelos de uma perfeição que deve ser buscada como ideal. Não se deve voltar a eles, mas buscar o que eles tinham intuitivamente, naturalmente, pela via da reflexão e da cultura, tarefa que só pode ser realizada no âmbito da poesia. Neste sentido histórico, a reflexão sobre antigos e modernos em Poesia ingênua e sentimental encontra um equilíbrio entre a noção de um modelo dos antigos e a defesa da poesia moderna.

\section{REFERÊNCIAS}

PRINCIPAIS

GOETHE, Wolfgang. Werke in sechs Banden. Frankfurt: Insel Verlag, 1993. . Essays on art and literature. The Collected Works. New Jersey: Princeton

University Press, 1994. v. 3. . Écrits sur l'art. Paris: GF Flammarion, 1996.

. Memórias: Poesia e Verdade. 2. ed. Brasília: Editora da Universidade de

Brasília, 1986.

GOETHE; SCHILLER. Der Briefwechsel zwischen Goethe und Schiller. Frankfurt: Insel Verlag, 1977.

HEGEL, G. W. F. Cursos de estética. São Paulo: Edusp, 2001.

KANT, Immanuel. Crítica da faculdade do juízo. Rio de Janeiro: Forense, 1993.

LESSING, G. E. Laocoonte ou sobre as fronteiras da pintura e da poesia. São Paulo: Iluminuras, 1998. 
SCHILLER, Friedrich. Sämtliche Werke. Augsburg: Bechtermünz, 1998. . Schillers Werke. Nationalausgabe. Weimar: Hermann Böhlaus Nachfolger,

1969. . Sobre a arte trágica. In: . Teoria da Tragédia. São Paulo: E.P.U.,

1995. . Maria Stuart. Tradução de Manuel Bandeira. Rio de Janeiro: Civilização Brasileira, 1955. . Cartas sobre a educação estética do homem. São Paulo: Iluminuras, 1990. . Poesia ingênua e sentimental. São Paulo: Iluminuras, 1995. . A noiva de Messina. São Paulo: Cosac e Naify, 2004. . Kallias ou Sobre a Beleza. Tradução e Introdução de Ricardo Barbosa.

Rio de Janeiro: Zahar, 2002.

SCHLEGEL, Friedrich. Conversa sobre poesia. São Paulo: Iluminuras, 1994.

SCHELLING. Filosofia da arte. São Paulo: Edusp, 2001.

WINCKELMANN. Réflexions sur l'imitation des æeuvres grecques en pinture et sculpture. Alerçon (Orne): Aubier, 1990. (Coleção bilíngüe).

\section{SECUNDÁRIAS}

BARBOSA, Ricardo. Schiller e a cultura estética. Rio de Janeiro: Zahar, 2004.

BENJAMIN, Walter. Dos ensayos sobre Goethe. Barcelona: Gedisa, 1996.

BUTLER, E. M. The tiranny of Greece over Germany. Cambridge: Cambridge University Press, 1935.

CARPEAUX, Otto Maria. Literatura alemã. São Paulo: Nova Alexandria, 1994.

CASSIRER, Ernst. Idee und Gestalt - Goethe, Schiller, Hölderlin, Kleist. Bei Bruno Cassirer. Berlim: [s.n.], 1921.

ECKERMANN. Conversações com Goethe. Lisboa: Vega, [s.d.].

KOOPMANN, Helmut. Friedrich Schiller I (1759-1794). Stuttgart: J. B. Metzlersche Verlagsbuchhandlung, 1966.

LUKÁCS, Georg. Goethe und seine Zeit. Berlim: Aufbau, 1950.

MANN, Thomas. Ist Schiller noch lebendig?. In: . Leiden und Grösse der Meister. Frankfurt: Fischer, 1982.

ROSENFELD, Anatol. O teatro moderno. São Paulo: Perspectiva, 1977.

STAËL, Madame de. De l'Allemagne. Paris: Garnier-Flamarion, 1968.

SZONDI, Peter. Ensaio sobre o trágico. Rio de Janeiro, Zahar, 2004. . Theorie des modernen Dramas (1880-1950). Frankfurt: Suhrkamp, 1957. . Schriften I. Frankfurt: Suhrkamp, 1978. . Das Naive ist das Sentimentalische. In: . Schriften II. Frankfurt:

Suhrkamp, 1978. . Antike und moderne in der Ästhetik der Goethezeit. In: . Poetik und Geschichtsphilosophie I. Studienausgabe der Vorlesungen Band 2. Frankfurt: Suhrkamp, 1974. 
WELLEK, René. Geschichte der Literaturkritik 1750-1830. Darmstadt-BerlinNeuwied: Luchterhand, 1959. 